\title{
Academy under fire over plans for new study of DNA statistics.
}

Washington. Less than two years after publishing a highly influential report on the use of DNA technology in forensic science, the US National Academy of Sciences (NAS) is about to launch a new, fast-track study of the use of DNA evidence in court cases.

But proposals for the new study have infuriated scientists and lawyers who fear it could undermine the recommendations of the original report. The critics charge that the Federal Bureau of Investigations (FBI) used improper methods to press for the study, and to confine its scope to an examination of statistics.

The report has been requested by the FBI. The Academy will conduct the work through its research arm, the National Research Council (NRC), and says that the report is needed to take account of new data published since the original study.

William Sessions, the former FBI director, asked for the study last April, claiming in particular the need to incorporate new data. He requested that it focus in particular on the use of the so-called "ceiling principle" in the statistical evaluation of DNA evidence. This uses conservative 'guesstimates' to evaluate the probability of a DNA match in cases where the data does not exist to support a more accurate estimate.

The principle has been widely used in court cases since being proposed in the first academy study. Its intention was to reduce detailed discussion of uncertainties involved in very low probabilities. In practice, however, it has often been used by defence lawyers to convince courts that there is too great a chance of a false conviction in cases depending on DNA evidence, resulting in recurrent acquittals both in the United States and elsewhere.

Critics are concerned that the new study will issue revised rules on statistical evaluation that are more to the liking of prosecutors and the FBI, and that its exclusive focus on statistics will undermine other parts of the old report which the FBI wishes to ignore, such as the requirement for forensic laboratories to publish error rates after independent inspection.

If it proceeds, the study will be conducted by a panel chaired by population geneticist James Crow of the University of Wisconsin, and will take just over six months to complete. It will proceed only if the NRC can raise the $\$ 300,000$ needed to pay for it. So far, it has received more than half that amount from the National Institute of Justice (NIJ) - a sister agency of the FBI in the Department of Justice - and smaller contributions from the National Institutes of Health and the Department of Energy.
Critics argue that the personal request from Sessions led the NRC to overrule the advice of its own Commission on Life Sciences, and proceed with the study. They also cite a letter from John Hicks, assistant director of the FBI laboratories division, to the director of the National Institute of Justice, as evidence that NIJ funding for the study was conditional on its scope being restricted to statistics.

Richard Lewontin of Harvard University, a population geneticist whose work strongly influenced the first report, has written to Bruce Alberts, the president of the Academy, attacking the FBI's conduct and warning that "there is no way that the NAS/ NRC can come out of this affair undamaged if it persists" with the report.

In his letter, Lewontin suggests that the new panel will either be dominated by scientists sympathetic to the FBI - in which case it will be seen as "rigged" - or it will be balanced "by others like me", ensuring "divisiveness, struggle and confusion for the courts and the scientific community."

Another population geneticist, Jerry Coyne of the University of Chicago, says he is "not convinced" that the new data justify a new study, and that he is "disturbed by the willingness of the National Academy to do the bidding of the FBI." Peter Neufeld, cochair of the DNA Task Force at the National
Association of Criminal Defense Lawyers, says the Academy "has been compromised" by the its decision to do the report.

But Bruce Alberts stands by the decision of the NRC under his predecessor, Frank Press, to go ahead, saying that new data have enabled people to dispute the original report's findings. "My feeling is that we have to go back and look at it again," he says. "I think we would have to do that independent of the FBI's view."

"There were plenty of checks and balances along the way here," says Eric Fischer, chair of the NRC's biology board and project director for the new report. The NRC has two reasons to proceed with the report, says Fischer: it was requested to do so by a federal agency - the FBI - and is required to respond; and there is "extra data and analysis" now published and available to do an update, denying that a focus on statistical evaluation will block out other issues.

But Eric Lander of the Whitehead Institute at Cambridge, Massachusetts, a member of the panel that produced the original report, says the update is only necessary because the administration failed to meet the panel's call for a "standing committee" to keep its recommendations up to date. "There's lots of new information and new evidence, but no mechanism for dealing with it," he says.

Colin Macilwain

\section{... as confusion leads to retrial in UK}

London. The Court of Appeal in London has ordered the retrial of a man convicted of rape after being identified through DNA evidence alone, because of confusion over the way in which the statistical interpretation of the DNA evidence was presented at his original trial.

The court ruled that evidence given by one of the forensic scientists, and the summing up of the judge, had fallen into the socalled 'prosecutor's fallacy' - the term used to describe confusion between two methods used to interpret the significance of an ap-

IMAGE
UNAVAILABLE
FOR
COPYRIGHT
REASONS

The ruling may prompt a flood of similar appeals that DNA evidence had been wrongly interpreted to juries. Indeed, it is already fuelling the heated debate in the United Kingdom and the United States (see above) about how to ensure the reliable use of DNA profiling techniques in the courtroom.

"This is the biggest straw that has been given to defence lawyers seeking to pick holes in the use of DNA evidence for a long time," says John Brookfield, a geneticist at the University of Nottingham. "I fear that this one will run and run."

The defendant, Andrew Deen, had been arrested during a random police check in Manchester, afterhis DNA profile was found to 'match' that of semen samples taken from a student who had been raped shortly beforehand. In February 1990, Deen was sentenced to 16 years in prison for this and two other rapes in the area.

Last summer, however, the appeals court agreed to hear evidence in Deen's defence, and in particular criticisms of the way in which DNA evidence was handled during his trial. The lawyer who prepared Deen's defence, Mike Mansfield, had previously obtained the release of the 'Birmingham 
Six', partly on the grounds that the forensic evidence used to convict them for pub bombings in the $1970 \mathrm{~s}$ was flawed.

Mansfield argued that although the ten bands used to compare Deen's DNA samples with those of the victim matched perfectly, the potential significance of discrepancies in two other bands had not been sufficiently explained to the jury.

$\mathrm{He}$ also argued that one of the prosecution's expert witnesses, as well as the judge, had confused two different sorts of probability. One is the probability that DNA from an individual selected at random from the population would match that of the semen taken from the rape victim, a calculation generally based solely on the frequency of different alleles in the population.

The other is the separate probability that a match between a suspect's DNA and that taken from the scene of a crime could have arisen simply by chance - in other words that the suspect is innocent despite the apparent match. This probability depends on the other factors that led to the suspect being identified as such in the first place.

During the trial, a forensic scientist gave the first probability in reply to a question about the second. Mansfield convinced the appeals court that the error was repeated by the judge in his summing up, and that this slip - widely recognized as a danger in any trial requiring the explanation of statistical arguments to a lay jury - justified a retrial.

In their judgement, the three appeal judges, headed by the Lord Chief Justice, Lord Farquharson, explicitly stated that their decision "should not be taken to indicate that DNA profiling is an unsafe source of evidence".

Nevertheless, with DNA techniques being increasingly used in court cases, some forensic scientists are worried that flaws in the presentation of their statistical significance could, as in the Deen case, undermine what might otherwise be a convincing demonstration of a suspect's guilt.

Some now argue, for example, that quantified statistical probabilities should be replaced, wherever possible, by a more descriptive presentation of the conclusions of their analysis. "The whole issue of statistics and DNA profiling has got rather out of hand," says one.

Others, however, say that the Deen case has been important in revealing the dangers inherent in the 'prosecutor's fallacy'. They argue that this suggests the need for more sophisticated calculation and careful presentation of statistical probabilities.

"The way that the prosecution's case has been presented in trials involving DNAbased identification has often been very unsatisfactory," says David Balding, lecturer in probability and statistics at Queen Mary and Westfield College in London. "Warnings about the prosecutor's fallacy should be made much more explicit. After this decision, people are going to have to be more careful."

David Dickson

\section{France gives broader role to defence research panel}

Paris. The French minister of defence, François Leotard, last week expanded the Scientific Council for Defence - the committee that advises the government on defence research - to include more representatives from universities, public research organizations and private industry.

Leotard described the main purpose of this move as being to make "tighter and more coordinated links" between civil and military research. But it is also being seen as a step towards a single integrated approach to technology policy, covering both the civilian and the military sector.

The head of the enlarged council will be André Giraud, a former head of the French Atomic Energy Commission (CEA). Giraud himself created the council in 1986 when he was minister of defence in the conservative government of Jacques Chirac.

Since then, its main activity has been to study specific areas of weapons technology at the request of ministers. In its expanded role, the council will monitor all advances in research for their potential impact not only on new weapons systems but also on other activities, including civilian industry.

This change highlights two trends. One is that the French military is turning to civilian science because, according to Leo-

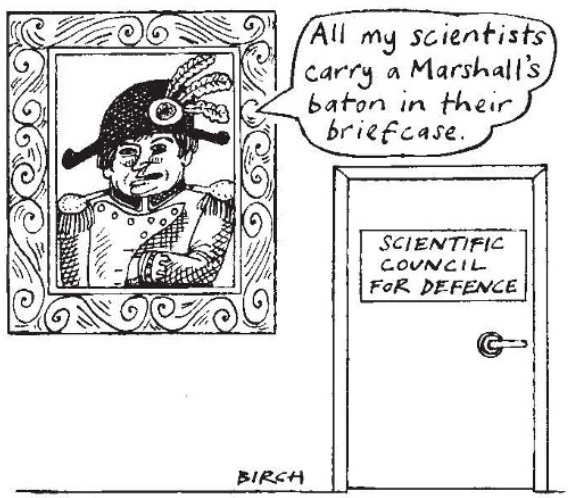

tard, it has belatedly recognized that, despite having given priority to its own research efforts in the past, France (like the rest of Europe) still lags behind the United States in fields such as space and computer technology and advanced avionics.

The French military can no longer afford to carry out such research on its own, particularly now that defence budgets are falling, and is therefore turning both to the civilian sector and to its European colleagues.

The other factor behind the decision to expand the scope of the council's work, says Alain Quenzer, its permanent secretary, is that France is broadening its concept of national defence beyond that of providing weapons systems to defend its territory, to protecting its "image and international influence, including its economic strength and science base".

In the short term, it is also clear that France hopes to save some of the 104,000 jobs expected to disappear in the arms industry before 1997 by converting parts of the military-industrial complex to civilian goals.

Behind both trends are the implications of the end of the Cold War. One concern in France is that Europe will end up perched on a US-Russian axis. To avoid this, France seems likely abandon its autonomy in weapons systems and support a European effort; a recent report to the government recommended that it share the cost of developing weapons (except nuclear) and other military technology with its European partners.

Observers in Paris feel that both initiatives are likely to propose increased funding for 'dual' high-technology research of both military and commercial interest. They may also lead to a reappraisal of the grands programmes technologiques in nuclear science, aeronautics and space, which still absorb much of France's research spending.

Quenzer says, for example, that although the grands programmes have been successful, the emphasis laid on them has led to neglect of other industrially important areas such as lasers and robotics. He says that a reorganization of the existing programmes is being discussed in order to produce greater industrial benefits, given that their political and strategic importance has been reduced by recent geopolitical changes.

The new council's first task will be to evaluate the importance of biology to defence. Quenzer says that France is concerned that developing countries could develop biological weapons, using advances in genetic engineering, for example, to produce cheaper and simpler weapons than nuclear bombs

But the government's moves are not without their critics. François Clapier, a researcher at the CNRS' Institut de Physique Nucléaire at Orsay, and secretary of the Group of Scientists for Nuclear Disarmament, says he is disappointed that France has not grasped the opportunities offered by the end of the Cold War to boost civilian research.

Clapier says France should be reducing military spending, rather than increasing its weapons research effort and extending it into new areas such as biology. He is also worried that "dual" research may turn out to be a euphemism for "handing control of the civil science budget to the military".

Declan Butler 